\title{
The Application of a Three-Step Proteome Analysis for Identification of New Biomarkers of Pancreatic Cancer
}

\author{
Mayinuer Abulaizi, 1, 2 Takeshi Tomonaga,, ${ }^{1,3}$ Mamoru Satoh,, 2 Kazuyuki Sogawa,, 2 \\ Kazuyuki Matsushita, ${ }^{1,2}$ Yoshio Kodera, ${ }^{2,4}$ Jurat Obul, ${ }^{1}$ Shigetsugu Takano, ${ }^{5}$ \\ Hideyuki Yoshitomi, ${ }^{5}$ Masaru Miyazaki, ${ }^{5}$ and Fumio Nomura ${ }^{1,2}$ \\ ${ }^{1}$ Department of Molecular Diagnosis, Graduate School of Medicine, Chiba University, Chiba 260-8670, Japan \\ ${ }^{2}$ Clinical Proteomics Research Center, Chiba University Hospital, Chiba 260-8677, Japan \\ ${ }^{3}$ Laboratory of Proteome Research, National Institute of Biomedical Innovation, Osaka 567-0085, Japan \\ ${ }^{4}$ Laboratory of Biomolecular Dynamics, Department of Physics, Kitasato University School of Science, Sagamihara 252-0373, Japan \\ ${ }^{5}$ Department of General Surgery, Graduate School of Medicine, Chiba University, 260-8670 Chiba, Japan
}

Correspondence should be addressed to Mayinuer Abulaizi, ablizmaynur@gmail.com

Received 31 May 2011; Accepted 2 August 2011

Academic Editor: Tadashi Kondo

Copyright (C 2011 Mayinuer Abulaizi et al. This is an open access article distributed under the Creative Commons Attribution License, which permits unrestricted use, distribution, and reproduction in any medium, provided the original work is properly cited.

\begin{abstract}
We searched for novel tumor markers of pancreatic cancer by three-step serum proteome analysis. Twelve serum abundant proteins were depleted using immunoaffinity columns followed by fractionation by reverse-phase high-performance liquid chromatography. Proteins in each fraction were separated by two-dimensional gel electrophoresis. Then the gel was stained by Coomassie Brilliant Blue. Protein spots in which the expression levels were significantly different between cancer and normal control were identified by LC-MS/MS. One hundred and two spots were upregulated, and 84 spots were downregulated in serum samples obtained from patients with pancreatic cancers, and 58 proteins were identified by mass spectrometry. These candidate proteins were validated using western blot analysis and enzyme-linked immunosorbent assay (ELISA). As a result of these validation process, we could confirm that the serum levels of apolipoprotein A-IV, vitamin D-binding protein, plasma retinolbinding protein 4 , and tetranectin were significantly decreased in patients with pancreatic cancer.
\end{abstract}

\section{Introduction}

Pancreatic cancer is one of the most lethal malignancies, with a 5-year survival rate of only 4-5\% [1]. The major reasons for the poor prognosis may be late diagnosis and limited therapeutic options; early diagnosis of pancreatic cancer is a pressing clinical problem.

Serum levels of the conventional tumor markers including carcinoembryonic antigen (CEA) and the Lewis blood group carbohydrate antigen (CA19-9) often remain in normal range at early stages of this malignancy [2]. Therefore, search for novel biomarkers of pancreatic cancer is needed.

Recent advances in proteomic technologies have provided promising ways to discover and identify novel biomarkers in various fields of clinical medicine. Although there has been long and uncertain path from marker discovery to clinical utility [3], sophisticated technologies have facilitated the discovery of potential tumor markers with improved sensitivities and specificities for the diagnosis of cancer patients [4]. Also, proteome analysis can lead to biomarkers that may be useful in the prediction of clinical response to anticancer therapy [5].

Surface enhanced laser desorption/ionization time-offlight mass spectrometry (SELDI-TOF MS) is a representative example of a proteomics technique for the highthroughput fingerprinting of serum proteins and peptides and biomarker discovery [6]. Using this technology, we could detect and identify novel diagnostic markers for alcohol abuse [7] and also a new prognostic marker for pancreatic cancer [8].

One of the technical challenges in serum proteome analysis is that serum contains thousands of proteins and peptides 
that are present in a large dynamic concentration [9]. Indeed, 22 abundant proteins such as albumin, immunoglobulins, and transferring constitute up to $99 \%$ of the protein content of plasma [10]. In proteomic studies searching for lowabundance serum proteins or peptides, depletion of those abundant proteins and further fractionation of samples will be necessary.

We recently conducted a three-step proteome analysis involving removal of 12 abundant proteins and subsequent reversed-phase high-performance liquid chromatography fractionation and one-dimensional electrophoresis: we successfully identified three proteins including YKL-50 as a promising biomarker of sepsis [11].

Proteomics in pancreatic cancer research including serum or plasma biomarker search has been reviewed [12]. A three-step approach as-we used in this study has not been tried in biomarker search for pancreatic cancers before.

In this study, we applied this three-step proteome analysis to find novel biomarkers of pancreatic cancer.

\section{Method}

2.1. Patients Studied. Serum samples were obtained preoperatively from a total of 32 patients diagnosed with primary invasive pancreatic ductal carcinoma who had surgery at the Department of General Surgery, Chiba University Hospital. Clinical data of 32 patients are summarized in Table 1(a). Serum samples were also obtained from apparently healthy and age-matched subjects who had medical checkup at the Port-square Kashiwado Clinic, Kashiwado Memorial Foundation (Table 1(b)). All samples were frozen by liquid nitrogen and were stored at $-80^{\circ} \mathrm{C}$ until analysis. Written informed consent was obtained from all the subjects. The ethics committee of our institute approved the protocol.

\subsection{A Three-Step Serum Proteome Analysis}

2.2.1. Immunoaffinity Subtraction of Highly Abundant Proteins from Human Serum. Serum samples obtained from 4 patients with pancreatic cancer (Nos $1 \sim 4$ in Table 1(a)) were pooled. Sera obtained from 4 age-matched healthy volunteers were also pooled (Nos $1 \sim 4$ in Table 1(b)). As the first step of proteome analysis, the twelve most abundant proteins (albumin, Immunoglobulin G, transferrin, fibrinogen, Immunoglobulin A, Immunoglobulin $\mathrm{M}$, apolipoprotein A-I, apolipoprotein A-II, haptoglobin, $\alpha 1$-acid glycoprotein and $\alpha 2$-macroglobulin) were removed from serum by passage through a commercially available immunoaffinity column, the ProteomeLab IgY12HC LC10 (Beckman coulter, Inc. Fullerton, CA. USA.) Ninety microliters of each pooled sample was subjected to the immunoaffinity subtraction as we previously described [11]. The combined flow-through fractions were concentrated by Vivaspin 2 spin concentrators (molecular weight cutoff, $10 \mathrm{kDa}$, Vivascience, Hannover, Germany) and were stored at $-80^{\circ} \mathrm{C}$ until use.

In addition, sera from 32 patients with pancreatic cancer and 32 healthy volunteers were used for validation. Eight healthy controls and 8 of relatively advanced cases (Nos $1 \sim 8$ in Tables 1(a) and 1(b)) were chosen for first validation and
24 of them (Nos 9 32 in Tables 1(a) and 1(b)) were used for the second validation experiment.

\subsection{HPLC Separation of Immunoaffinity-Subtracted Serum} Samples. Immunoaffinity-subtracted serum samples prepared as described above were separated by reverse-phase HPLC in an automated HPLC system, the SHISEIDO Nanospace SI-2 (Shiseido Fine Chemicals, Tokyo, Japan) essentially as we described before [11]. A total of 40 fractions were collected at $0.5 \mathrm{~min}$ intervals from 19.6 to $39.6 \mathrm{~min}$. Each fraction was immediately lyophilized by a centrifugal vacuum concentrator and stored at $-80^{\circ} \mathrm{C}$ until further analysis.

2.4. Two-Dimensional Gel Electrophoresis. The IEF gels (70 $\mathrm{mm}$ length, Inner $2.5 \mathrm{~mm}$ diameter and $\mathrm{pH}$ ranges from 3 to 10$)$ were prepared as previously described $[13,14]$. The lyophilized samples (from fraction 6 to fraction 25) were dissolved with $15 \mu \mathrm{L}$ sample preparation buffer and proteins were separated by two-dimensional gel electrophoresis with agarose gels in the first dimension as described by Oh-Ishi et al. [13].

2.5. In-Gel Digestion and LC-MS/MS. CBB stained 2-DE images of pooled serum samples obtained from patients with pancreatic cancer were compared with those obtained from healthy volunteers. Differentially expressed protein bands were excised from the gel and were subjected to in-gel tryptic digestion as previously reported [14]. Digested peptides were injected into a trap column: $0.3 \times 5 \mathrm{~mm}$ L-trap column (Chemicals Evaluation and Research Institute, Saitama, Japan) and an analytical column: $0.1 \times 50 \mathrm{~mm}$ Monolith column (AMR, Tokyo, Japan), which was attached to a HPLC system (Nanospace SI-2; Shiseido Fine Chemicals, Tokyo, Japan). The flow rate of a mobile phase was $1 \mu \mathrm{L} / \mathrm{min}$. The solvent composition of the mobile phase was programmed to change in $35 \mathrm{~min}$ cycles with varying mixing ratios of solvent $\mathrm{A}\left(2 \% \mathrm{v} / \mathrm{v} \mathrm{CH} \mathrm{CH}_{3} \mathrm{CN}\right.$ and $\left.0.1 \% \mathrm{v} / \mathrm{v} \mathrm{HCOOH}\right)$ to solvent $\mathrm{B}\left(90 \% \mathrm{v} / \mathrm{v} \mathrm{CH}_{3} \mathrm{CN}\right.$ and $\left.0.1 \% \mathrm{v} / \mathrm{v} \mathrm{HCOOH}\right): 5-50 \% \mathrm{~B}$ $20 \mathrm{~min}, 50-95 \%$ B $1 \mathrm{~min}, 95 \%$ B $3 \mathrm{~min}, 95-5 \%$ B $1 \mathrm{~min}, 5 \%$ B $10 \mathrm{~min}$. Purified peptides were introduced from HPLC to an LTQ-XL (Thermo Scientific, CA, USA), an ion trap mass spectrometer (ITMS), via an attached Pico Tip (New Objective, MA, USA). The MS and MS/MS peptide spectra were measured in a data-dependent manner according to the manufacturer's operating specifications. The Mascot search engine (Matrixscience, London, UK) was used to identify proteins from the mass and tandem mass spectra of peptides. Peptide mass data were matched by searching the Human International Protein Index database (IPI, July 2008, 72079 entries, European Bioinformatics Institute) using the MASCOT engine. The minimum criterion of the probability-based MASCOT/MOWSE score was set with 5\% as the significant threshold level. When the candidates had SEQUEST scores lower than 100 or when the SEQEUST score was computed by using fewer than one peptides fragment, we inspected the raw MS and MS/MS spectra of peptides to judge their qualities (see Figures a-f in Supplementary Material available online at doi: 10.1155/2011/628787). 
TABLe 1

(a) Clinical features of pancreatic cancer patients.

\begin{tabular}{|c|c|c|c|c|c|c|c|c|}
\hline No & Gender & Age (years) & UICC-stage & Tumor size $(\mathrm{mm})$ & $\mathrm{TP}(\mathrm{g} / \mathrm{dL})$ & $\operatorname{ALB}(\mathrm{g} / \mathrm{dL})$ & Che (U/L) & T-Cho $(\mathrm{mg} / \mathrm{dL})$ \\
\hline 1 & $\mathrm{M}$ & 66 & III & 35 & 6.7 & 4.3 & 270 & 220 \\
\hline 2 & $\mathrm{M}$ & 66 & III & 39 & 6.6 & 4.4 & 359 & 198 \\
\hline 3 & $\mathrm{M}$ & 79 & IV & 10 & 6.2 & 3.8 & 179 & 155 \\
\hline 4 & $\mathrm{M}$ & 71 & III & 18 & 6.8 & 4.0 & 207 & 210 \\
\hline 5 & $\mathrm{M}$ & 65 & III & 35 & 7.0 & 3.7 & 189 & 131 \\
\hline 6 & $\mathrm{M}$ & 78 & III & 50 & 6.6 & 4.4 & 359 & 198 \\
\hline 7 & $\mathrm{M}$ & 66 & IIA & 30 & 6.3 & 4.1 & 267 & 176 \\
\hline 8 & $\mathrm{M}$ & 62 & IV & 10 & 5.9 & 3.6 & 171 & 169 \\
\hline 9 & $\mathrm{M}$ & 38 & IA & 10 & 6.7 & 4.0 & 289 & 179 \\
\hline 10 & $\mathrm{M}$ & 50 & IB & 30 & 7.3 & 4.6 & 408 & 203 \\
\hline 11 & $\mathrm{M}$ & 63 & IIA & 18 & 6.6 & 3.9 & 260 & 138 \\
\hline 12 & $\mathrm{M}$ & 62 & IIA & 38 & 6.0 & 3.4 & 124 & 149 \\
\hline 13 & $\mathrm{M}$ & 54 & IIA & 24 & 7.0 & 4.5 & 198 & 162 \\
\hline 14 & $\mathrm{M}$ & 73 & IIA & 25 & 6.7 & 4.1 & 242 & 176 \\
\hline 15 & $\mathrm{~F}$ & 76 & IIA & 26 & 5.0 & 3.3 & 162 & 95 \\
\hline 16 & $\mathrm{M}$ & 63 & IIB & 15 & 7.1 & 4.2 & 175 & 163 \\
\hline 17 & $\mathrm{M}$ & 65 & IIB & 32 & 5.8 & 3.5 & 227 & 113 \\
\hline 18 & $\mathrm{M}$ & 68 & IIB & 80 & 6.8 & 4.0 & 316 & 217 \\
\hline 19 & $\mathrm{M}$ & 71 & IIB & 24 & 7.5 & 4.1 & 221 & 144 \\
\hline 20 & $\mathrm{M}$ & 74 & IIB & 27 & 7.0 & 4.3 & 319 & 178 \\
\hline 21 & $\mathrm{~F}$ & 68 & IIB & 27 & 6.5 & 4.0 & 223 & 177 \\
\hline 22 & $\mathrm{M}$ & 63 & IIB & 26 & 6.9 & 4.3 & 262 & 219 \\
\hline 23 & $\mathrm{~F}$ & 68 & IIB & 27 & 6.1 & 3.5 & 339 & 163 \\
\hline 24 & $\mathrm{M}$ & 61 & IIB & 30 & 6.2 & 4.0 & 200 & 176 \\
\hline 25 & F & 74 & IIB & 40 & 6.6 & 3.8 & 221 & 170 \\
\hline 26 & $\mathrm{M}$ & 62 & IIB & 60 & 8.3 & 3.5 & 140 & 155 \\
\hline 27 & $\mathrm{~F}$ & 73 & IIB & 35 & 5.9 & 3.2 & 130 & 169 \\
\hline 28 & $\mathrm{~F}$ & 59 & IIB & 18 & 7.2 & 4.4 & 356 & 130 \\
\hline 29 & $\mathrm{M}$ & 73 & IIB & 50 & 5.7 & 3.3 & 127 & 135 \\
\hline 30 & $\mathrm{~F}$ & 62 & IIB & 25 & 6.8 & 4.1 & 255 & 293 \\
\hline 31 & $\mathrm{~F}$ & 71 & III & 25 & 6.8 & 4.2 & 294 & 159 \\
\hline 32 & $\mathrm{~F}$ & 78 & III & 50 & 5.9 & 3.3 & 197 & 182 \\
\hline Ave \pm SD & & $66 \pm 8.6$ & & $30.9 \pm 15.0$ & $6.6 \pm 0.6$ & $3.9 \pm 0.4$ & $240.2 \pm 75.6$ & $171.9 \pm 6.6$ \\
\hline
\end{tabular}

UICC: international union against cancer, M: male, F: female. TP: total protein. ALB: albumin. Che: cholinesterase. T-Cho: total cholesterol. Ave: average. SD: standard deviation.

From number 1 to 4 were used for 2-DE, from number 1 to 8 were for first western blot, from number 9 to 32 were for second western blot.

(b) Clinical features of healthy controls.

\begin{tabular}{|c|c|c|c|c|c|c|}
\hline No & Gender & Age (years) & $\mathrm{TP}(\mathrm{g} / \mathrm{dL})$ & $\operatorname{ALB}(\mathrm{g} / \mathrm{dL})$ & Che (U/L) & T-Cho $(\mathrm{mg} / \mathrm{dL})$ \\
\hline 1 & M & 62 & 7.5 & 4.7 & 401 & 203 \\
\hline 2 & M & 61 & 7.7 & 5.1 & 396 & 269 \\
\hline 3 & $\mathrm{M}$ & 64 & 7.2 & 4.4 & 284 & 229 \\
\hline 4 & $\mathrm{M}$ & 73 & 7.6 & 4.7 & 216 & 203 \\
\hline 5 & M & 57 & 8.3 & 5.0 & 430 & 301 \\
\hline 6 & M & 57 & 6.7 & 4.8 & 328 & 253 \\
\hline 7 & M & 65 & 7.2 & 4.8 & 375 & 230 \\
\hline 8 & M & 64 & 7.2 & 4.6 & 327 & 296 \\
\hline
\end{tabular}


(b) Continued.

\begin{tabular}{|c|c|c|c|c|c|c|}
\hline No & Gender & Age (years) & $\mathrm{TP}(\mathrm{g} / \mathrm{dL})$ & $\operatorname{ALB}(\mathrm{g} / \mathrm{dL})$ & Che (U/L) & T-Cho (mg/dL) \\
\hline 9 & M & 55 & 6.9 & 4.6 & 300 & 211 \\
\hline 10 & M & 71 & 7.1 & 4.7 & 290 & 267 \\
\hline 11 & $\mathrm{~F}$ & 64 & 8.1 & 5.4 & 293 & 192 \\
\hline 12 & $\mathrm{M}$ & 71 & 7.2 & 4.5 & 233 & 213 \\
\hline 13 & $\mathrm{M}$ & 55 & 7.2 & 4.5 & 365 & 227 \\
\hline 14 & $\mathrm{M}$ & 68 & 7.4 & 4.4 & 300 & 255 \\
\hline 15 & $\mathrm{~F}$ & 67 & 7.0 & 4.5 & 279 & 172 \\
\hline 16 & $\mathrm{~F}$ & 71 & 7.0 & 4.5 & 297 & 220 \\
\hline 17 & $\mathrm{M}$ & 60 & 6.7 & 4.2 & 284 & 183 \\
\hline 18 & $\mathrm{M}$ & 61 & 7.0 & 4.7 & 260 & 198 \\
\hline 19 & $\mathrm{M}$ & 55 & 6.4 & 3.9 & 304 & 176 \\
\hline 20 & $\mathrm{~F}$ & 70 & 7.6 & 4.7 & 398 & 225 \\
\hline 21 & M & 70 & 7.3 & 4.6 & 257 & 250 \\
\hline 22 & $\mathrm{~F}$ & 67 & 7.4 & 4.5 & 304 & 194 \\
\hline 23 & $\mathrm{M}$ & 60 & 7.0 & 4.4 & 338 & 234 \\
\hline 24 & $\mathrm{~F}$ & 77 & 8.1 & 5.0 & 416 & 274 \\
\hline 25 & $\mathrm{~F}$ & 62 & 7.5 & 4.6 & 284 & 169 \\
\hline 26 & $\mathrm{~F}$ & 64 & 7.2 & 4.5 & 280 & 208 \\
\hline 27 & M & 65 & 7.4 & 4.6 & 264 & 231 \\
\hline 28 & M & 61 & 7.8 & 4.3 & 319 & 239 \\
\hline 29 & $\mathrm{M}$ & 61 & 7.3 & 4.6 & 309 & 271 \\
\hline 30 & M & 66 & 7.5 & 5.0 & 375 & 278 \\
\hline 31 & $\mathrm{~F}$ & 65 & 7.6 & 4.5 & 339 & 288 \\
\hline 32 & M & 73 & 7.1 & 4.4 & 306 & 211 \\
\hline Ave $\pm S D$ & & $64.4 \pm 5.7$ & $7.3 \pm 0.4$ & $4.6 \pm 0.3$ & $317 \pm 53.4$ & $230.3 \pm 36.9$ \\
\hline
\end{tabular}

M: male, F: female. TP: total protein. ALB: albumin. Che: cholinesterase. T-Cho: total cholesterol. Ave: average. SD: standard deviation.

From number 1 to 4 were used for 2-0 E, from number 1 to 8 were for first western blot, from number 9 to 32 were for second western blot.

2.6. Western Blot Analysis. Western blotting was performed as we previously described [15].

Briefly, immunoaffinity-subtracted serum samples were separated on SDS-PAGE in 10-20\% polyacrylamide gradient gel (DRC, Tokyo, Japan) and were transferred to polyvinylidene fluoride membranes $(0.45 \mu \mathrm{m}$ thickness, Millipore, Bedford, MA) at $10 \mathrm{~V}$ for overnight. The following antibodies commercially available were used as primary antibodies; mouse anti-human ApoA-IV antibody (BML Inc., Tokyo, Japan), mouse anti-human GC antibody (LifeSpan, Inc., UK), mouse monoclonal anti-human RBP4 antibody (Abnova.Com., Taipei, Taiwan) and mouse anti-human CLEC3B antibody (BioPorto, Grusbakken 8, DK-2820 Gentofte, Denmark). Antigens on the membrane were detected with enhanced chemiluminescence detection reagents (GE Healthcare). Band intensities of the western blot images were quantified by TotalLab TL12 imaging analysis software (Shimadzu Co., Ltd. Kyoto, Japan) and were presented by arbitrary units.

2.7. Other Procedures. In addition to western blotting, ELISA was conducted in some marker candidates using human
ApoA-IV ELISA kit (Millipore, Missouri, USA), GC ELISA kit (immundiagnostik AG, Bensheim), and RBP4 ELISA kit; ( R \& D systems). Their optical density was measured at $450 \mathrm{~nm}$ using a microplate reader (iMark Microplate Reader S/N 10288). Serum levels of CEA and CA19-9 were determined by established commercially available kits.

2.8. Statistical Analysis. Statistical analysis was conducted using KaleidaGraph 4.0 J (Synergy Software, Reading, PA) and IBM SPSS Statistics 18 (SPSS Inc., IL, USA). Significance was defined as $P<0.05$.

\section{Results}

3.1. Discovery and Identification of Differentially Expressed Proteins by a Three-Step Proteome Analysis. To discover and identify novel serum markers for pancreatic cancer, we employed a comparative three-step proteome analysis of the pooled serum samples obtained from patients with pancreatic cancer and healthy volunteers. As the first step, 12 abundant proteins were removed by immunosubtractions. The immunoaffinity-subtracted samples were separated by 


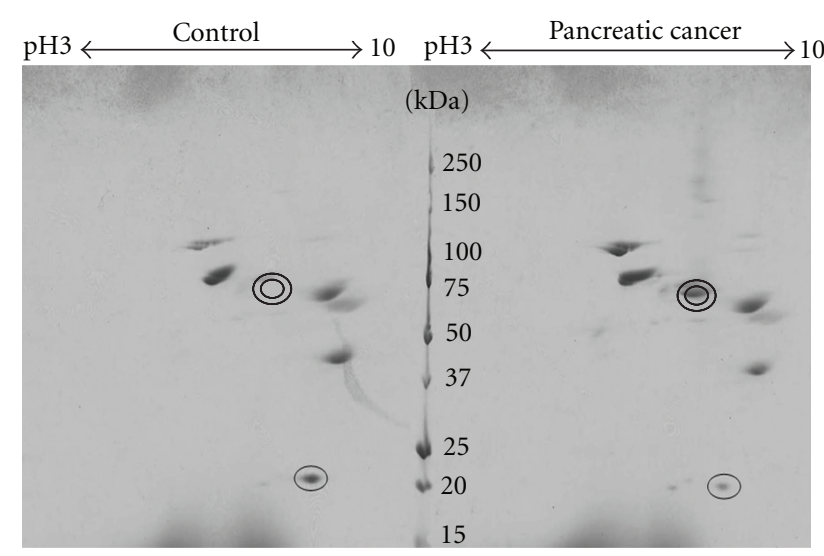

Figure 1: Comparison of 2-DE images of the same fraction of healthy volunteer control and pancreatic cancer patient sample. Electrophoresis was performed on the same gel and at the same condition. Figure 1 is an example of Coomassie blue-stained gel displaying spots from depleted and fractionated serum from control (left, $n=4$, pooled) and pancreatic cancer patients (right, $n=$ 4 , pooled). (Fraction number is 10 th). Double circles indicate increased spot in pancreatic cancer. Single circle indicates decreased spot in pancreatic cancer.

RP-HPLC, and 20 fractions (fractions Nos 6-25) were subjected to 2-DE. A representative example is shown in Figure 1. By comparing the 2-DE images of the proteins included in the 20 fractions, a total 186 spots were found to be differently expressed. Subsequent LC-MS/MS could identify 100 proteins. Excluding keratins, complements and trypsin, 58 proteins were selected; 37 of them were upregulated and 21 were downregulated (Tables 2(a) and 2(b)).

3.2. Validation of Marker Candidates by Western Blotting. Out of the 58 proteins listed in Tables 2(a) and 2(b), we focused on 19 proteins the alterations of which at serum level have not been studied in detail before, and also antibodies to be used for validation studies are available. Initial validation was conducted using 8 serum samples (nos. $1-8$ in Table 1) obtained from relatively advanced cases with pancreatic cancer including the four cases used for the three-step analysis. Western blotting of the 19 proteins indicated in Tables 2(a) and 2(b) revealed that expression of 7 proteins were found to be significantly decreased in patients with pancreatic cancers compared with controls: they were interalpha trypsin inhibitor heavy chain H1 (ITIH1), hemopexin precursor (HPX), alpha-1B-glycoprotein precursor (A1BG), apolipoprotein A-IV precursor (ApoA-IV), vitamin Dbinding protein precursor (GC), plasma retinol-binding protein precursor (RBP4), and tetranectin (CLEC3B).

We then conducted the second validation study to test whether differential expression of the 7 protein candidates described above is reproducible using another set of serum samples obtained from 24 patients with pancreatic cancers including cases with relatively early stages (nos. 9-32 in Table 1(a)). As shown in Figure 2(a) the expression levels of the four proteins ApoA-IV, GC, RBP4, and CLEC3B were greater in cancer patients than in controls. The differences were statistically significant assessed by densitometry Figure 2(b).

3.3. Validation of Marker Candidates by ELISA. ELISA kits were commercially available for GC, ApoA-IV, and RBP4. Their serum levels were determined in the 15 pairs of serum samples obtained from relatively early stages of patients used for the second validation by western blotting. Serum ApoAIV levels of patients with pancreatic cancer $(107.8 \pm 99.9 \mathrm{AU})$ were significantly lower than those in healthy volunteers (195.2 \pm 66.9 AU, $P=0.008)$ Figure 3(a). GC levels were significantly lower in the patient group with pancreatic cancer $(25.4 \pm 10 \mathrm{UA})$ when compared with healthy group (34.3 \pm 10.3 AU, $P=0.03)$ Figure 3(b). Also, serum RBP levels in the patients $(43.0 \pm 5.9 \mathrm{AU})$ were significantly lower than in the controls $(50.2 \pm 4.2, P=0.0004)$ Figure $3(\mathrm{c})$.

\subsection{Comparison of the Marker Candidates with CEA and} CA19-9. Figure 4 shows the receiver-operating characteristic curve (ROC) analysis for the three marker candidates determined by ELISA and those for CEA and CA19-9. The areas under the curves for ApoA-IV, GC, RBP4, CA19-9, and CEA were $0.79,0.72,0.85,0.88,0.58,0.88,0.89$, and 0.89 , respectively. Also, AUCs of the combination assay of GC/CA19-9, ApoA-IV/CA19-9, and RBP/CA19-9 were 0.88, 0.89 , and 0.89 , respectively.

In Tables 3(a) and 3(b), serum levels of ApoA-IV, GC and RBP4 determined by ELISA are listed together with CEA and CA19-9. There were 7 cases in which serum CA19-9 level was not elevated. Out of these 7 cases, ApoA-IV levels were below the lower reference interval value (mean SD) in 2 cases. Also, GC levels were below the lower reference interval value in one case.

\section{Discussion}

The sequencing of the human genome has opened the door for comprehensive analysis of all the messenger RNA (transcriptome) and proteins (proteome). Messenger RNA concentrations, however, are not necessarily predictive of corresponding protein concentrations. Indeed, a recent report indicates that the sharing rate between cDNA microarray and proteome-based profilings is limited for the identification of candidate biomarkers in renal cell carcinoma [16]. Therefore, proteome analysis is one of the prerequisite for development of novel biomarkers. Proteomic studies in pancreatic cancers have been conducted by many research groups as reviewed $[12,17]$. Hwang et al. found by using 2-DE/MS that phosphoglycerate kinase (PGK) 1, a secretable glycolytic enzyme involved in angiogenesis, is overexpressed in serum samples of pancreatic cancer patients, as compared to controls [18]. More recently, using the two-dimensional image-converted analysis of liquid chromatography and mass spectrometry (2DICAL) and a "glyco capturing" through concanavalin Aagarose, Ono et al. identified a novel prolyl-hydroxylation of fibrinogen alpha chain in plasma samples obtained from patients with pancreatic cancers [19]. 
TABLE 2

(a) Proteins upregulated in pancreatic cancer.

\begin{tabular}{|c|c|c|c|c|c|}
\hline Protein's name & $\begin{array}{c}\text { Experimental } \\
\text { mass }(\mathrm{Da})\end{array}$ & $\begin{array}{l}\text { Theoretical } \\
\text { mass (Da) }\end{array}$ & Score $^{(1)}$ & $\begin{array}{c}\text { Queries } \\
\text { matched }^{(2)}\end{array}$ & Validation \\
\hline Histidine-rich glycoprotein precursor & 80000 & 59541 & 150 & 3 & $\mathrm{WB}^{(3)}$ \\
\hline Plasminogen precursor & 100000 & 90510 & 331 & 8 & \\
\hline IGHM protein & 50000 & 52754 & 105 & 2 & \\
\hline TF Serotransferrin precursor & 75000 & 77000 & 601 & 14 & WB \\
\hline Isoform LMW of Kininogen-1 precursor & 70000 & 47853 & 242 & 6 & \\
\hline F2 Prothrombin precursor (Fragment) & 90000 & 69992 & 486 & 8 & \\
\hline Alpha-1B-glycoprotein precursor & 43000 & 54239 & 590 & 8 & WB \\
\hline Vitronectin precursor & 62000 & 54271 & 581 & 8 & WB \\
\hline Hepatocyte growth factor-like protein precursor & 85000 & 80268 & 284 & 6 & WB \\
\hline Plasma kallikrein precursor & 90000 & 71323 & 246 & 8 & \\
\hline Ceruloplasmin precursor & 115000 & 122128 & 1452 & 49 & \\
\hline Isoform 1 of Ficolin-3 precursor & 34400 & 32883 & 58 & 1 & \\
\hline Transthyretin precursor & 95000 & 15877 & 4489 & 13 & \\
\hline Serum amyloid P-component precursor & 24000 & 25371 & 2293 & 12 & \\
\hline Antithrombin III variant & 61000 & 52658 & 1984 & 20 & \\
\hline SERPINC1 protein & 61000 & 29074 & 1147 & 11 & \\
\hline Carbonic anhydrase 1 & 30800 & 28852 & 679 & 10 & WB \\
\hline Isoform 1 of C-reactive protein precursor & 26000 & 25023 & 169 & 6 & \\
\hline Apolipoprotein A-1 & 31600 & 30759 & 225 & 4 & \\
\hline Isoform 1 of Inter-alpha-trypsin inhibitor heavy chain $\mathrm{H} 3$ & 138000 & 75031 & 529 & 12 & \\
\hline Leucine-rich alpha-2-glycoprotein precursor & 47000 & 38154 & 549 & 8 & \\
\hline Isoform 1 of $\mathrm{N}$-acetylmuramoyl-L-alanine amidase precursor & 68900 & 67957 & 193 & 4 & \\
\hline Xaa-Pro dipeptidase & 53700 & 54513 & 144 & 3 & \\
\hline Inter-alpha (globulin) inhibitor $\mathrm{H} 4$ & 130500 & 103261 & 1242 & 26 & WB \\
\hline Vitamin K-dependent protein S precursor & 84000 & 75074 & 136 & 4 & WB \\
\hline Serpin peptidase inhibitor, clade D (Heparin cofactor), & 72000 & 57034 & 374 & 9 & \\
\hline Isoform 1 of Fibronectin precursor & 200000 & 262442 & 553 & 14 & WB \\
\hline Alpha-1-antichymotrypsin precursor & 62800 & 50566 & 3315 & 33 & WB \\
\hline Kallistatin precursor & 59600 & 48511 & 123 & 2 & \\
\hline Plastin-2 & 72000 & 70245 & 215 & 5 & \\
\hline Corticosteroid-binding globulin precursor & 62500 & 45112 & 52 & 1 & \\
\hline Myosin-1 & 31600 & 222976 & 96 & 2 & \\
\hline Isoform 1 of Serum albumin precursor & 73000 & 69321 & 261 & 9 & \\
\hline Cholinesterase precursor & 83000 & 72836 & 50 & 1 & \\
\hline $\mathrm{AMBP}$ protein precursor & 200000 & 38974 & 68 & 1 & \\
\hline Plasma protease $\mathrm{C} 1$ inhibitor precursor & 87000 & 55119 & 1168 & 15 & \\
\hline Apolipoprotein B-100 precursor & 300000 & 515241 & 3982 & 117 & \\
\hline
\end{tabular}

${ }^{(1)}$ MOWSE score of candidate proteins.

(2) Number of peptide fragments yielding informative MS/MS.

${ }^{(3)} \mathrm{WB}$ : western blot.

(b) Proteins downregulated in pancreatic cancer.

\begin{tabular}{|c|c|c|c|c|c|}
\hline Protein's name & $\begin{array}{c}\text { Experimental } \\
\text { mass }(\mathrm{Da})\end{array}$ & $\begin{array}{l}\text { Theoretical } \\
\text { mass (Da) }\end{array}$ & Score ${ }^{(1)}$ & $\begin{array}{c}\text { Queries } \\
\text { matched }^{(2)}\end{array}$ & Validation \\
\hline Plasma retinol-binding protein precursor & 19000 & 22995 & 373 & 8 & $\mathrm{WB}^{(3)}$ \\
\hline Coagulation factor XII precursor & 75000 & 67774 & 140 & 5 & \\
\hline Tetranectin precursor & 19000 & 22552 & 61 & 1 & WB \\
\hline Hyaluronan-binding protein 2 precursor & 68000 & 62630 & 195 & 6 & \\
\hline
\end{tabular}


(b) Continued.

\begin{tabular}{|c|c|c|c|c|c|}
\hline Protein's name & $\begin{array}{c}\text { Experimental } \\
\text { mass (Da) }\end{array}$ & $\begin{array}{l}\text { Theoretical } \\
\text { mass (Da) }\end{array}$ & Score ${ }^{(1)}$ & $\begin{array}{c}\text { Queries } \\
\text { matched }^{(2)}\end{array}$ & Validation \\
\hline Vitamin D-binding protein precursor & 55000 & 52883 & 284 & 14 & WB \\
\hline Hemopexin precursor & 75000 & 51643 & 635 & 8 & WB \\
\hline Lumican precursor & 100000 & 38405 & 120 & 6 & WB \\
\hline Isoform 1 of Gelsolin precursor & 80000 & 85644 & 1360 & 23 & WB \\
\hline Afamin precursor & 80000 & 69024 & 307 & 7 & \\
\hline Carboxypeptidase $\mathrm{N}$ catalytic chain precursor & 49000 & 52253 & 244 & 12 & WB \\
\hline Inter-alpha-trypsin inhibitor heavy chain $\mathrm{H} 1$ precursor & 200000 & 101326 & 812 & 13 & WB \\
\hline Histone H4 & 25700 & 11360 & 59 & 1 & \\
\hline JUP JUP protein & 100000 & 81675 & 90 & 3 & \\
\hline apolipoprotein A-IV precursor & 42000 & 45371 & 2188 & 35 & WB \\
\hline Inter-alpha-trypsin inhibitor heavy chain $\mathrm{H} 2$ precursor & 200000 & 106370 & 1636 & 26 & WB \\
\hline Pigment epithelium-derived factor precursor & 50000 & 46313 & 529 & 11 & \\
\hline Angiotensinogen precursor & 56300 & 53121 & 986 & 13 & \\
\hline SERPINF2 protein & 58000 & 55029 & 75 & 2 & \\
\hline Actin, cytoplasmic 1 & 100000 & 41710 & 208 & 5 & \\
\hline Thrombospondin-1 precursor & 175000 & 129300 & 152 & 4 & \\
\hline Alpha-2-macroglobulin precursor & 180000 & 163175 & 559 & 18 & \\
\hline
\end{tabular}

${ }^{(1)}$ MOWSE score of candidate proteins.

${ }^{(2)}$ Number of peptide fragments yielding informative MS/MS data. The minimum significant threshold level of the probability-based MASCOT/MOWSE score was set at $5 \%$.

${ }^{(3)} \mathrm{WB}$ : western blot.

In this study, the three-step procedure was carried out to discover novel markers of pancreatic cancer. The outline of the three-step procedures is shown in Figure 5.

As a first step, serum samples were subjected to antibodybased immunoaffinity column that simultaneously removes 12 abundant serum proteins. The concentrated flow-through was then fractionated using reversed-phase HPLC. Proteins obtained in each HPLC fraction were further separated by 2-DE. A total of 58 differentially expressed proteins were identified. As results of initial validation by western blotting in relatively advanced cases and further validation including the less advanced cases by western blotting, the expression levels of the four proteins ApoA-IV, GC, RBP4, and CLEC3B were greater in cancer patients than in controls. Out of these four proteins, ELISA were available in apolipoprotein A-IV, retinol-binding protein precursor (RBP4), and vitamin D binding protein (GC). Serum levels of these 3 proteins were significantly lower in patients with pancreatic cancer than in healthy volunteers. In ROC analyses, the area under the curves for these three proteins was not significantly greater than that for CA19-9, but it is noteworthy that among the 4 cases of pancreatic cancers in which serum levels of both CEA and CA19-9 were within the reference intervals, at least one of ApoA-IV, RBP4, and GC was found to be decreased in 2 cases, suggesting that these candidate markers could be complementary to the conventional markers in diagnosis of pancreatic cancer.
ApoA-IV is present in human intestinal epithelial cells and is secreted as a chylomicron and VLDL apoprotein [20].

Retinol binding protein 4 (RBP4) is a $21-\mathrm{kDa}$ protein synthesized in the liver and adipose tissue; its major function is to deliver retinol to tissue [21]. Fabris et al. determined serum RBP levels in patients with pancreatic cancer and found that the levels decreased concomitant with zinc and prealbumin levels [22]. Serum zinc levels were not significantly correlated with RBP4 levels in the present study (data not shown).

Vitamin D-binding protein is a plasma protein involved in vitamin $\mathrm{D}$ transport and other function. Although diagnostic role of this protein in pancreas cancer has not been reported yet, inhibitory role of vitamin D binding protein-macrophage activating factor (DBP-maf) in pancreatic carcinogenesis has been pointed out [23].

Tetranectin binds to kringle 4 of plasminogen, enhancing the plasminogen activation by tissue-type plasminogen activator in the presence of poly-D-lysine [24] Low serum levels of tetranectin (CLEC3B) are associated with increased risk of second-line chemoresistance in patients with ovarian cancer [25]. Also, in colorectal cancer, significantly shorter survival was found for patients with CLEC3B levels below a cut-off point of compared to patients with levels above [26].

Thus, the results of this study show that four serum proteins, apolipoprotein A-IV, vitamin D binding protein, retinol-binding protein 4 , and tetranectin are significantly 


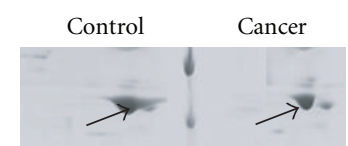

Apolipoprotein A-IV

(a1)

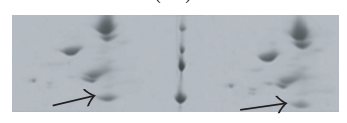

Vitamin D-binding protein

(a2)

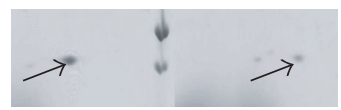

Retinol binding protein 4

(a3)

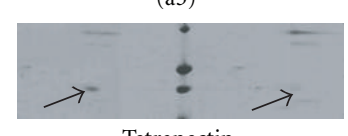

Tetranectin

(a4)

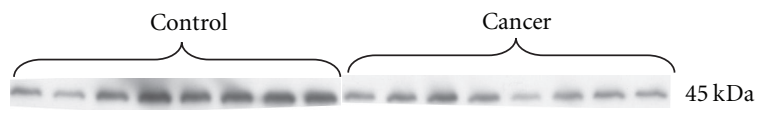

(b1)

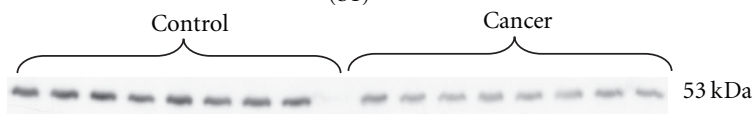

(b2)

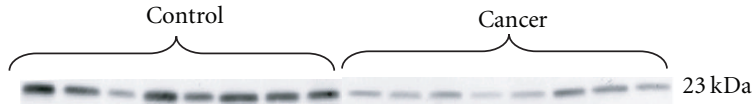

(b3)

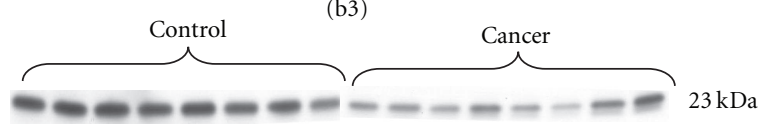

(b4)

(a)

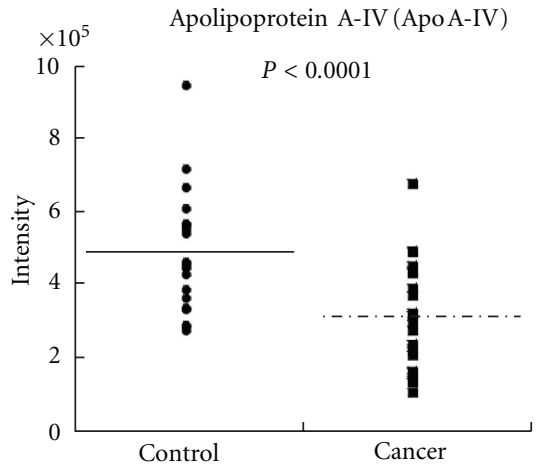

(A)

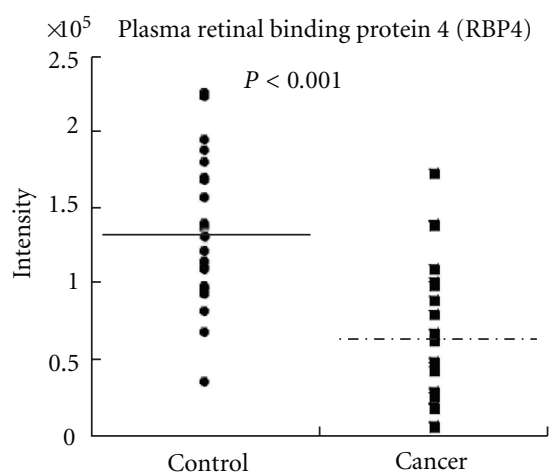

(C)

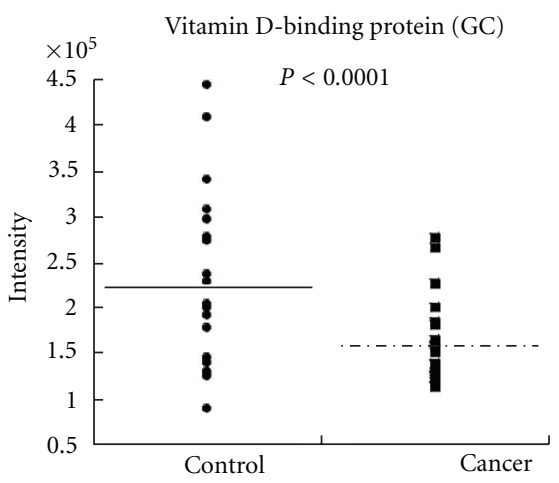

(B)

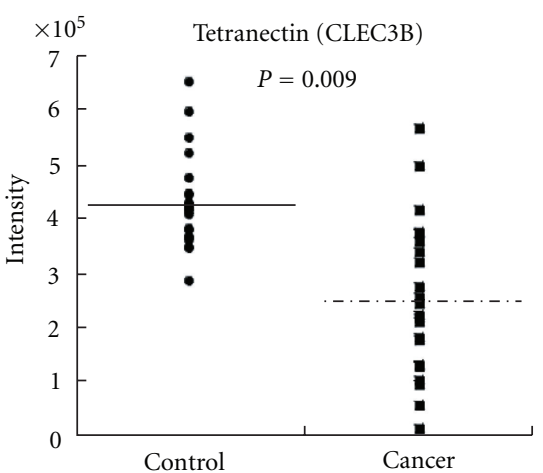

(D)

(b)

FIGURe 2: (a) Magnified views of 2-D gel images and western blotting analysis of ApoA-IV, GC, plasma retinol binding protein 4 RBP4, and CLEC3B in serum samples. Coomassie blue-stained 2-D gel images from pooled control and pancreatic cancer displaying the protein spots for ApoA-IV, GC, RBP4, and CLEC3B are shown in left panels (a1), (a2), (a3) and (a4). Western blotting of these four proteins are shown in the right panel (b1), (b2), (b3) and (b4). (b) Quantitation of differentially expressed serum proteins in pancreatic cancer and healthy volunteers by Western blot analysis. Intensities of each band were calculated by TotalLab TL 120 software. Closed circles indicate healthy volunteers and closed squares indicate patients with pancreatic cancer. Significance of the differences were calculated by using Wilcoxon Mann-Whitney test. Panel A: ApoA-IV levels of serum were significantly lower in the depleted sera of pancreatic cancer when compared with the depleted sera of healthy volunteers $(P<0.0001)$. Panel $(B, C$ and D) are for proteins GC, RBP4, and CLEC3B and their serum levels were likewise lower in the pancreatic cancer patients. Their $P$ values are lower than $0.0001,0.001$, and 0.009 , respectively. 


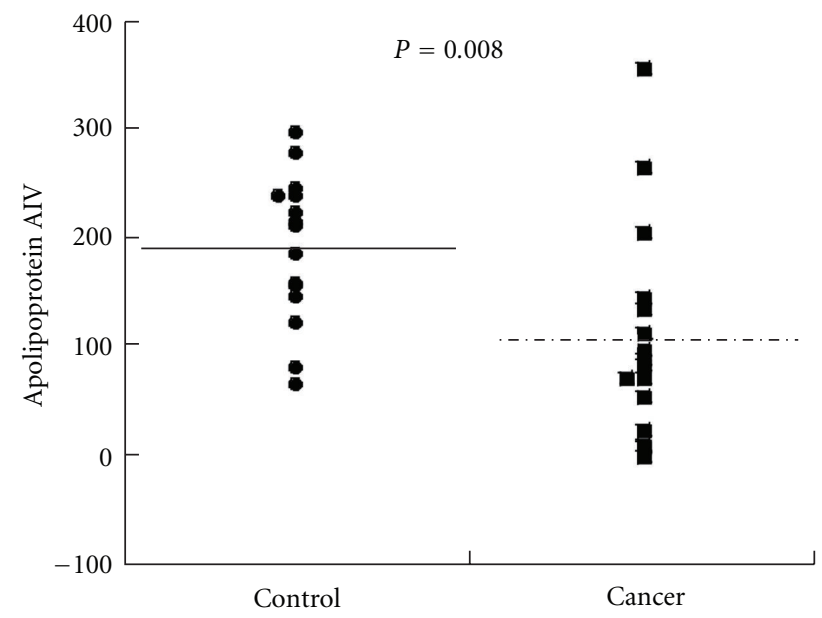

(a)

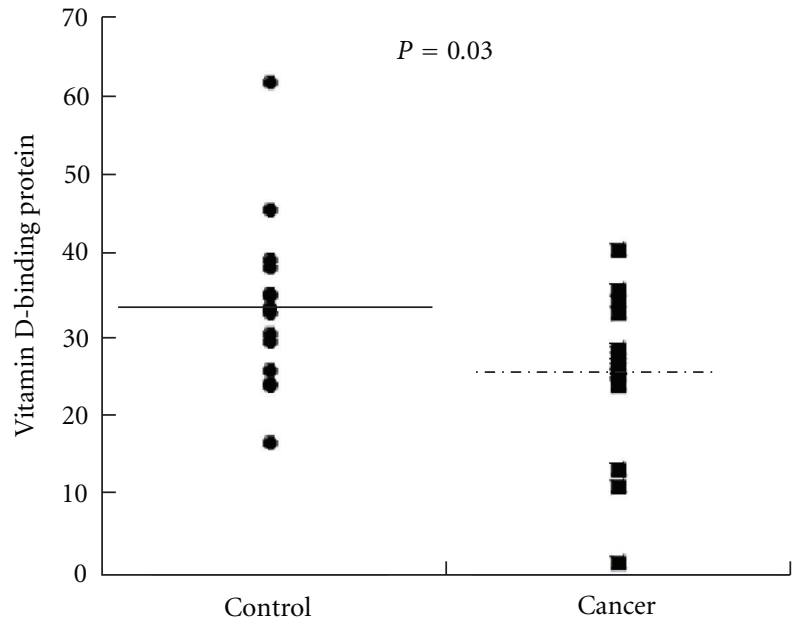

(b)

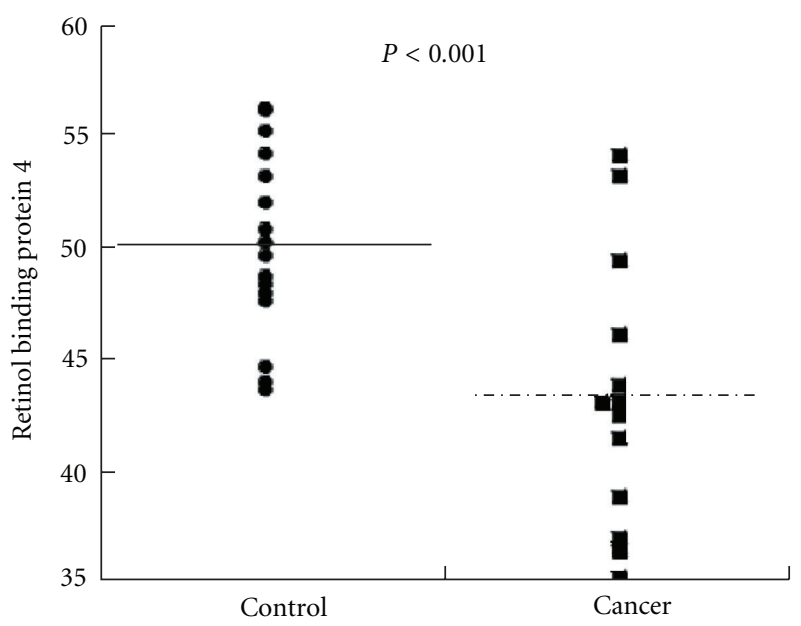

(c)

FIGURE 3: Quantitation of differentially expressed proteins in pancreatic cancer by ELISA. ELISA was performed using human ApoA-IV ELISA kit vitamin D binding protein ELISA kit and RBP4 ELISA kit, in serum samples obtained from 15 patients with pancreatic cancers and 15 control subjects. Analysis was performed by using Wilcoxon Mann-Whitney test. Closed circles indicate control and closed squares indicate cancer. (a): ApoA-IV levels of serum of patient with pancreatic cancer group (107.76 $\pm 25.8 \mathrm{AU})$ were lower than those in healthy group (185.27 $\pm 16.0 \mathrm{AU}, P=0.01)$; (b): GC levels were significantly lower in the patient group with pancreatic cancer $(25.35 \pm 9.8 \mathrm{UA})$ when compared with healthy group $(34.40 \pm 10.2 \mathrm{AU}, P=0.03)$; (c): RBP4 levels were lower in the pancreatic cancer group (42.99 $\pm 1.5 \mathrm{AU})$ than healthy group $(50.7 \pm 1.00 \mathrm{AU}, P<0.001)$.

decreased in patients with pancreatic cancer. It was notable that these changes were observed in some patients in whom conventional tumor markers for this malignancy were not altered.

The reasons why serum levels of these proteins were decreased in pancreatic cancer patients are not clear at the moment. It is unlikely that the alterations were entirely due to malnutrition because serum levels of the 4 proteins were not significantly correlated with their serum albumin levels. It is possible that some negative mediators originated from tumor and/or the cancer-tissue microenvironments were regulating their production. It is unlikely that the alterations were due to biliary obstruction because the extent of the alterations of the four markers were not related to the extent of biliary obstruction (data not shown). Alterations of these four proteins in chronic pancreatitis as well as biliary tract diseases remain to be studied. Also, it remains to be determined whether serum levels of these four proteins are changed in other gastroenterological cancers.

Although exact mechanisms responsible for the reduction remain to be investigated, alterations of serum levels of apolipoprotein A-IV, vitamin D binding protein, tetranectin, and retinol binding protein may have complementary role in diagnosis of pancreas cancer. 


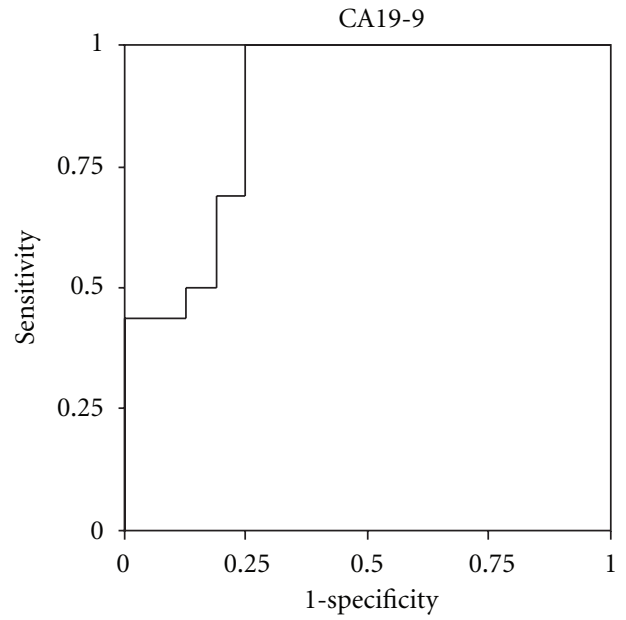

(a)

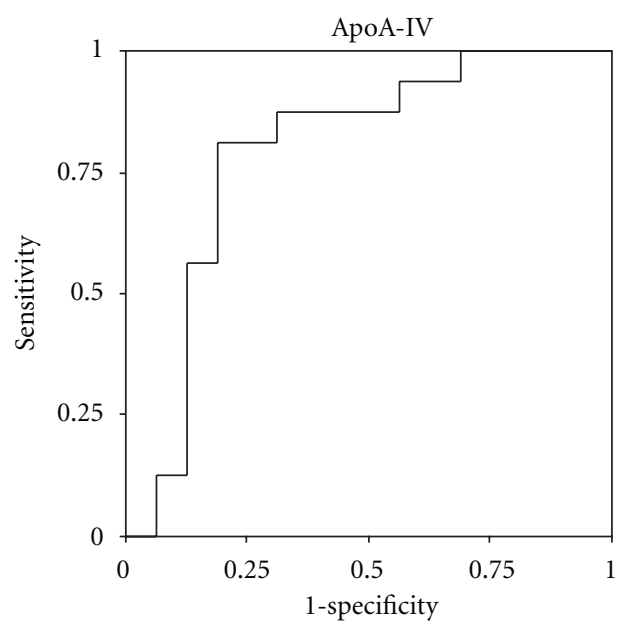

(c)

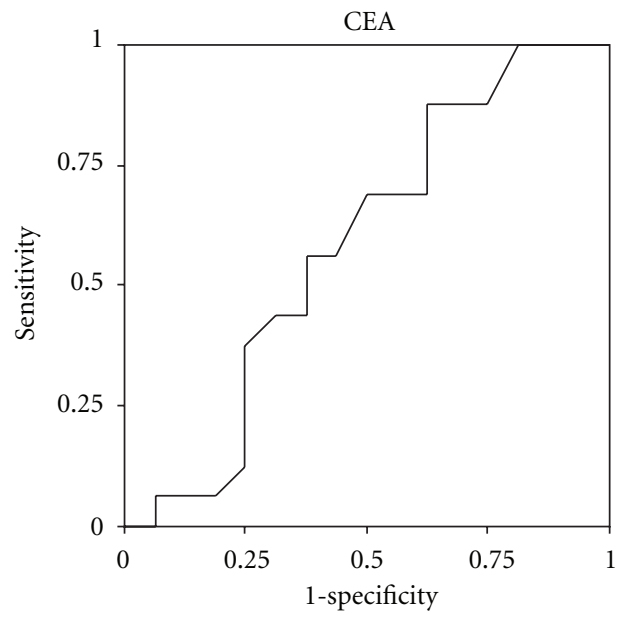

(b)

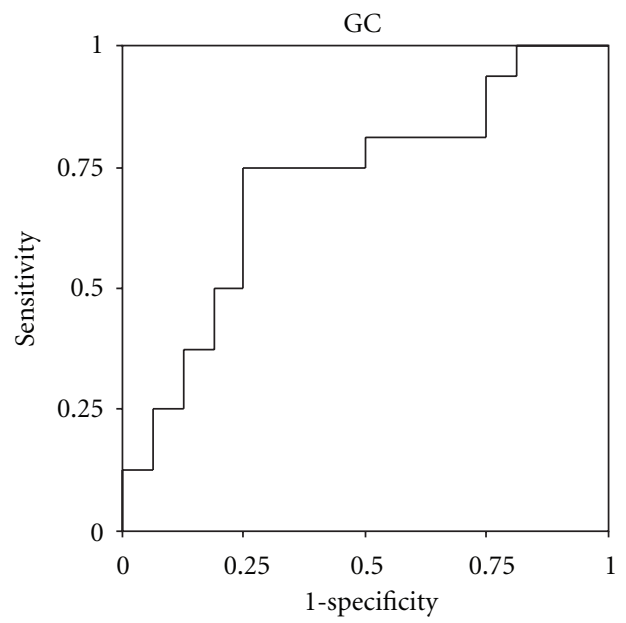

(d)

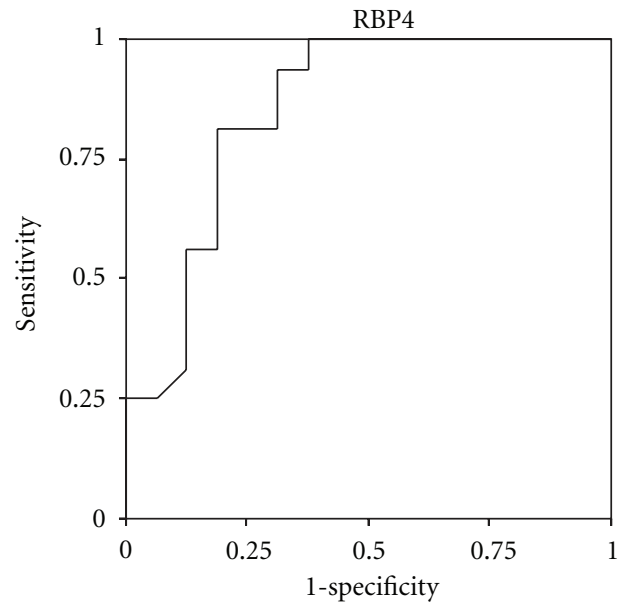

(e)

FIGURE 4: Receiver operating characteristic (ROC) curves for CA19-9, CEA, ApoA-IV, GC, RBP4 Their AUCs are described in the text. 
TABLE 3

(a) Serum tumor marker levels in patients with pancreatic cancer.

\begin{tabular}{|c|c|c|c|c|c|c|c|c|}
\hline Gender & Age (years) & UICC-stage & $\begin{array}{c}\text { Tumor size } \\
(\mathrm{mm})\end{array}$ & $\begin{array}{l}\text { CA19-9 } \\
(\mathrm{U} / \mathrm{mL}) \\
\end{array}$ & $\begin{array}{c}\text { CEA } \\
(\mathrm{ng} / \mathrm{mL})\end{array}$ & ApoA-IV (AU) & GC (AU) & RBP4 (AU) \\
\hline M & 38 & IA & 10 & 26.2 & 2.3 & 262.1 & 35.9 & 54.2 \\
\hline M & 50 & IB & 30 & 46.5 & 2.3 & 8.5 & 34.3 & 43.9 \\
\hline $\mathrm{M}$ & 63 & IIA & 18 & 157 & 1.1 & 10.2 & 26.7 & 37.0 \\
\hline $\mathrm{M}^{*}$ & 62 & IIA & 38 & 9 & 5 & 70.7 & 25.1 & 41.5 \\
\hline $\mathrm{M}^{*}$ & 54 & IIA & 24 & 11 & 1.4 & 87.5 & 11.3 & 42.5 \\
\hline M & 73 & IIA & 25 & 15.5 & 3.5 & 203.5 & 13.6 & 49.5 \\
\hline $\mathrm{F}^{*}$ & 76 & IIA & 26 & 13.3 & 1.5 & 70.7 & 33.1 & 43.2 \\
\hline M & 65 & IIB & 32 & 1579 & 3.4 & 352.1 & 24.3 & 36.7 \\
\hline$M^{*}$ & 74 & IIB & 27 & 10.9 & 3.4 & 0 & 28.0 & 35.3 \\
\hline $\mathrm{F}$ & 74 & IIB & 40 & 43 & 3.2 & 54 & 25.8 & 38.9 \\
\hline $\mathrm{F}$ & 68 & IIB & 27 & 302 & 2.1 & 82.8 & 40.8 & 36.4 \\
\hline M & 61 & IIB & 30 & 10 & 1.4 & 134.7 & 27.3 & 46.2 \\
\hline M & 63 & IIB & 15 & 1080 & - & 144.6 & 23.9 & 53.3 \\
\hline$M^{*}$ & 73 & IIB & 50 & 13.9 & 2.1 & 23.2 & 1.8 & 43.1 \\
\hline $\mathrm{F}$ & 62 & IIB & 25 & 11.5 & 1.1 & 111.7 & 28.4 & 43.1 \\
\hline Ave \pm SD & $63.7 \pm 10.4$ & & $27.8 \pm 9.9$ & $221.9 \pm 466.2$ & $63.7 \pm 10.4$ & $107.8 \pm 99.9$ & $25.4 \pm 10$ & $50.2 \pm 4.2$ \\
\hline
\end{tabular}

(b) Serum tumor marker levels in healthy controls.

\begin{tabular}{|c|c|c|c|c|c|c|}
\hline Gender & Age (years) & CA19-9 (u/mL) & CEA (ng/mL) & ApoA-IV (AU) & $\mathrm{GC}(\mathrm{AU})$ & RBP4 (AU) \\
\hline M & 71 & 33.9 & 2.2 & 157.4 & 29.5 & 47.7 \\
\hline $\mathrm{M}$ & 55 & 0.1 & 4.7 & 243.8 & 35.0 & 48.5 \\
\hline M & 55 & 6.4 & 1 & 223.0 & 35.3 & 54.3 \\
\hline M & 55 & 0.1 & 3.5 & 237.1 & 33.0 & 48.1 \\
\hline M & 60 & 7.7 & 0.8 & 237.1 & 23.9 & 44.1 \\
\hline M & 60 & 37.4 & 7 & 214.0 & 39.6 & 48.8 \\
\hline $\mathrm{M}$ & 61 & 7.6 & 4.8 & 277.0 & 16.8 & 49.7 \\
\hline $\mathrm{F}$ & 77 & 7.1 & 1.1 & 294.5 & 24.2 & 43.7 \\
\hline M & 61 & 7.8 & 1.3 & 80.6 & 33.4 & 55.3 \\
\hline $\mathrm{F}$ & 61 & 6 & 3 & 210.1 & 45.8 & 56.3 \\
\hline $\mathrm{F}$ & 65 & 2.9 & 2.1 & 65.7 & 61.7 & 53.3 \\
\hline $\mathrm{M}$ & 66 & 5.1 & 0.7 & 156.7 & 33.8 & 44.7 \\
\hline $\mathrm{F}$ & 62 & 11.7 & 1.7 & 122.9 & 33.0 & 50.9 \\
\hline $\mathrm{F}$ & 64 & 8.4 & 1.2 & 222.9 & 38.7 & 50.3 \\
\hline $\mathrm{F}$ & 71 & 24.4 & 2.6 & 184.7 & 30.5 & 56.3 \\
\hline Ave \pm SD & $62.9 \pm 6.3$ & $11.1 \pm 11.5$ & $2.5 \pm 1.8$ & $195.2 \pm 66.9$ & $34.3 \pm 10.3$ & $50.2 \pm 4.2$ \\
\hline
\end{tabular}


Three-step proteome analysis

Serum $90 \mu \mathrm{L}$ (4 pancreatic cancer, 4 healthy volunteers)

\section{$\downarrow$}

Immunodepletion of 12 major proteins (Beckman column)

40 fractionation (reversed-phase HPLC)

Agarose 2-DE/CBB staining

In-gel digestion, LC-MS/MS analysis

Western blot and ELISA

FIGURE 5: Outline of the procedure for the three-step serum proteome analysis.

\section{Acknowledgments}

The authors would like to thank Masanori Semiya for giving them helpful discussions and suggestions. Also, they thank Fumie Iida and Manami Miura for their technical supports.

\section{References}

[1] A. Jemal, R. Siegel, E. Ward et al., "Cancer statistics, 2006," Ca-A Cancer Journal for Clinicians, vol. 56, no. 2, pp. 106-130, 2006.

[2] G. Barugola, L. Frulloni, R. Salvia, and M. Falconi, "Is CA 19-9 a screening marker?" Digestive and Liver Disease, vol. 41, no. 5, pp. 325-327, 2009.

[3] N. Rifai, M. A. Gillette, and S. A. Carr, "Protein biomarker discovery and validation: the long and uncertain path to clinical utility," Nature Biotechnology, vol. 24, no. 8, pp. 971983, 2006.

[4] S. C. C. Wong, C. M. L. Chan, B. B. Y. Ma et al., "Advanced proteomic technologies for cancer biomarker discovery," Expert Review of Proteomics, vol. 6, no. 2, pp. 123-134, 2009.

[5] L. Smith, M. J. Lind, K. J. Welham, and L. Cawkwell, "Cancer proteomics and its application to discovery of therapy response markers in human cancer," Cancer, vol. 107, no. 2, pp. 232-241, 2006.

[6] L. C. Whelan, K. A. R. Power, D. T. McDowell, J. Kennedy, and W. M. Gallagher, "Applications of SELDI-MS technology in oncology," Journal of Cellular and Molecular Medicine, vol. 12, no. 5A, pp. 1535-1547, 2008.

[7] F. Nomura, T. Tomonaga, K. Sogawa et al., "Identification of novel and downregulated biomarkers for alcoholism by surface enhanced laser desorption/ionization-mass spectrometry," Proteomics, vol. 4, no. 4, pp. 1187-1194, 2004.

[8] Y. Shirai, K. Sagawa, T. Yamaguchi et al., "Protein profiling in pancreatic juice for detection of intraductal papillary mucinous neoplasm of the pancreas," Hepato-Gastroenterology, vol. 55, no. 86-87, pp. 1824-1829, 2008.
[9] N. L. Anderson and N. G. Anderson, "The human plasma proteome: history, character, and diagnostic prospects," Molecular \& Cellular Proteomics, vol. 1, no. 11, pp. 845-867, 2002.

[10] R. S. Tirumalai, K. C. Chan, D. A. Prieto, H. J. Issaq, T. P. Conrads, and T. D. Veenstra, "Characterization of the low molecular weight human serum proteome," Molecular \& Cellular Proteomics, vol. 2, no. 10, pp. 1096-1103, 2003.

[11] N. Hattori, S. Oda, T. Sadahiro et al., "YKL-40 identified by proteomic analysis as a biomarker of sepsis," Shock, vol. 32, no. 4, pp. 393-400, 2009.

[12] D. Cecconi, M. Palmieri, and M. Donadelli, "Proteomics in pancreatic cancer research," Proteomics, vol. 11, no. 4, pp. 816828, 2011.

[13] M. Oh-Ishi, M. Satoh, and T. Maeda, "Preparative two-dimensional gel electrophoresis with agarose gels in the first dimension for high molecular mass proteins," Electrophoresis, vol. 21, no. 9, pp. 1653-1669, 2000.

[14] M. Satoh, E. Haruta-Satoh, A. Omori et al., "Effect of thyroxine on abnormal pancreatic proteomes of the hypothyroid $\mathrm{rdw}$ rat," Proteomics, vol. 5, no. 4, pp. 1113-1124, 2005.

[15] T. Nishimori, T. Tomonaga, K. Matsushita et al., "Proteomic analysis of primary esophageal squamous cell carcinoma reveals downregulation of a cell adhesion protein, periplakin," Proteomics, vol. 6, no. 3, pp. 1011-1018, 2006.

[16] B. Seliger, S. P. Dressler, E. Wang et al., "Combined analysis of transcriptome and proteome data as a tool for the identification of candidate biomarkers in renal cell carcinoma," Proteomics, vol. 9, no. 6, pp. 1567-1581, 2009.

[17] I. Gräntzdörffer, S. Carl-McGrath, M. P. Ebert, and C. Röcken, "Proteomics of pancreatic cancer," Pancreas, vol. 36, no. 4, pp. 329-336, 2008.

[18] T. L. Hwang, Y. Liang, K. Y. Chien, and J. S. Yu, "Overexpression and elevated serum levels of phosphoglycerate kinase 1 in pancreatic ductal adenocarcinoma," Proteomics, vol. 6, no. 7, pp. 2259-2272, 2006.

[19] M. Ono, J. Matsubara, K. Honda et al., "Prolyl 4-hydroxylation of $\alpha$-fibrinogen. A novel protein modification revealed by plasma proteomics," Journal of Biological Chemistry, vol. 284, no. 42, pp. 29041-29049, 2009.

[20] P. H. R. Green, R. M. Glickman, J. W. Riley, and E. Quinet, "Human apolipoprotein A-IV. Intestinal origin and distribution in plasma," Journal of Clinical Investigation, vol. 65, no. 4, pp. 911-919, 1980.

[21] L. Quadro, W. S. Blaner, D. J. Salchow et al., "Impaired retinal function and vitamin A availability in mice lacking retinolbinding protein," EMBO Journal, vol. 18, no. 17, pp. 46334644, 1999.

[22] C. Fabris, A. Piccoli, and A. Meani, "Study of retinol-binding protein in pancreatic cancer," Journal of Cancer Research and Clinical Oncology, vol. 108, no. 2, pp. 227-229, 1984.

[23] O. Kisker, S. Onizuka, C. M. Becker et al., "Vitamin D binding protein-macrophage activating factor (DBP-maf) inhibits angiogenesis and tumor growth in mice," Neoplasia, vol. 5, no. 1, pp. 32-40, 2003.

[24] I. Clemmensen, L. Petersen Chr. L., and C. Kluft, "Purification and characterization of a novel, oligomeric, plasminogen kringle 4 binding protein from human plasma: tetranectin," European Journal of Biochemistry, vol. 156, no. 2, pp. 327-333, 1986. 
[25] B. Gronlund, E. V. S. Høgdall, I. J. Christensen et al., "Pre-treatment prediction of chemoresistance in second-line chemotherapy of ovarian carcinoma: value of serological tumor marker determination (tetranectin, YKL-40, CASA, CA 125)," International Journal of Biological Markers, vol. 21, no. 3, pp. 141-148, 2006.

[26] C. K. Høgdall, I. J. Christensen, R. W. Stephens, S. Sørensen, B. Nørgaard-Pedersen, and H. J. Nielsen, "Serum tetranectin is an independent prognostic marker in colorectal cancer and weakly correlated with plasma suPAR, plasma PAI-1 and serum CEA," Acta Pathologica, Microbiologica, et Immunologica Scandinavica, vol. 110, no. 9, pp. 630-638, 2002. 

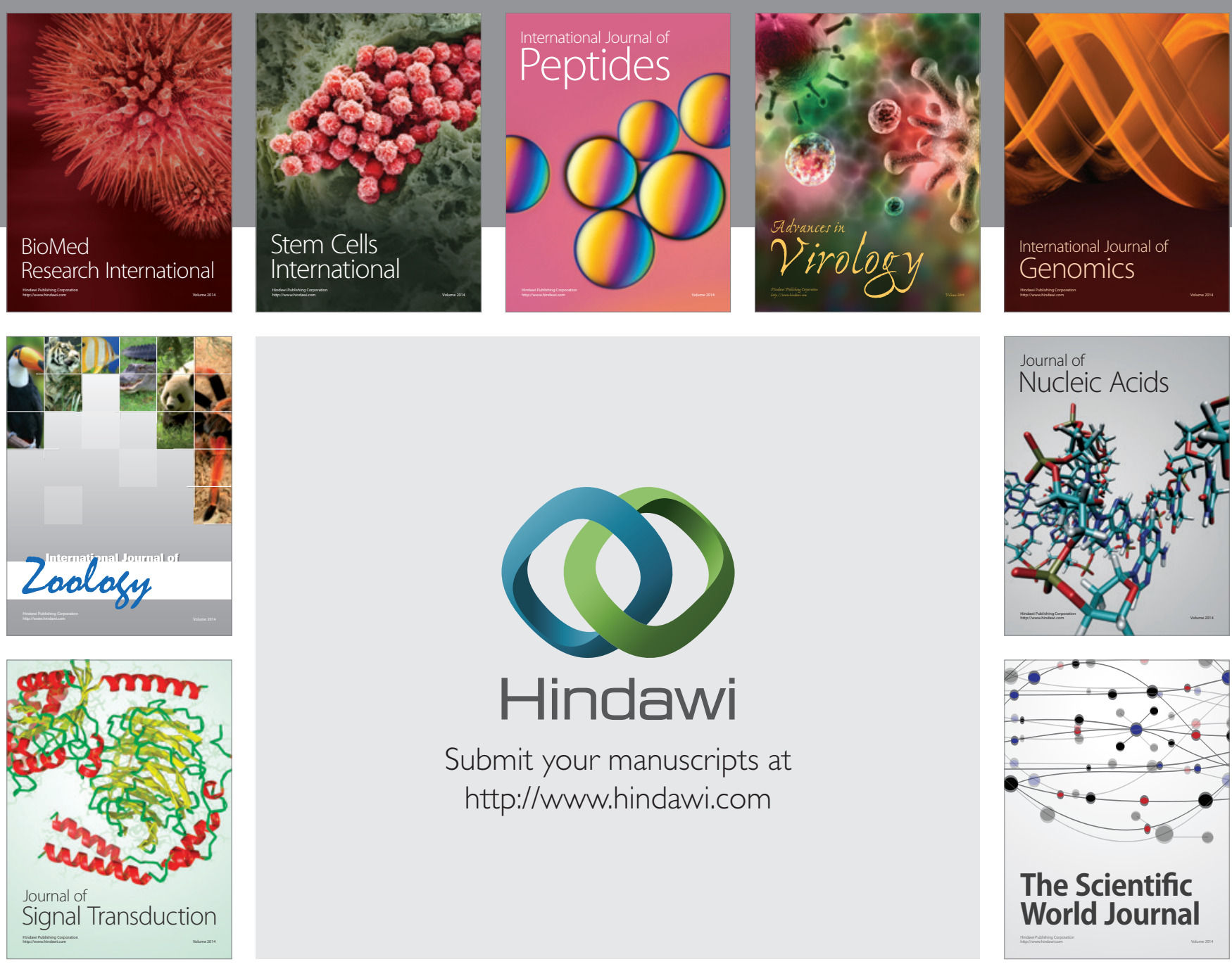

Submit your manuscripts at

http://www.hindawi.com
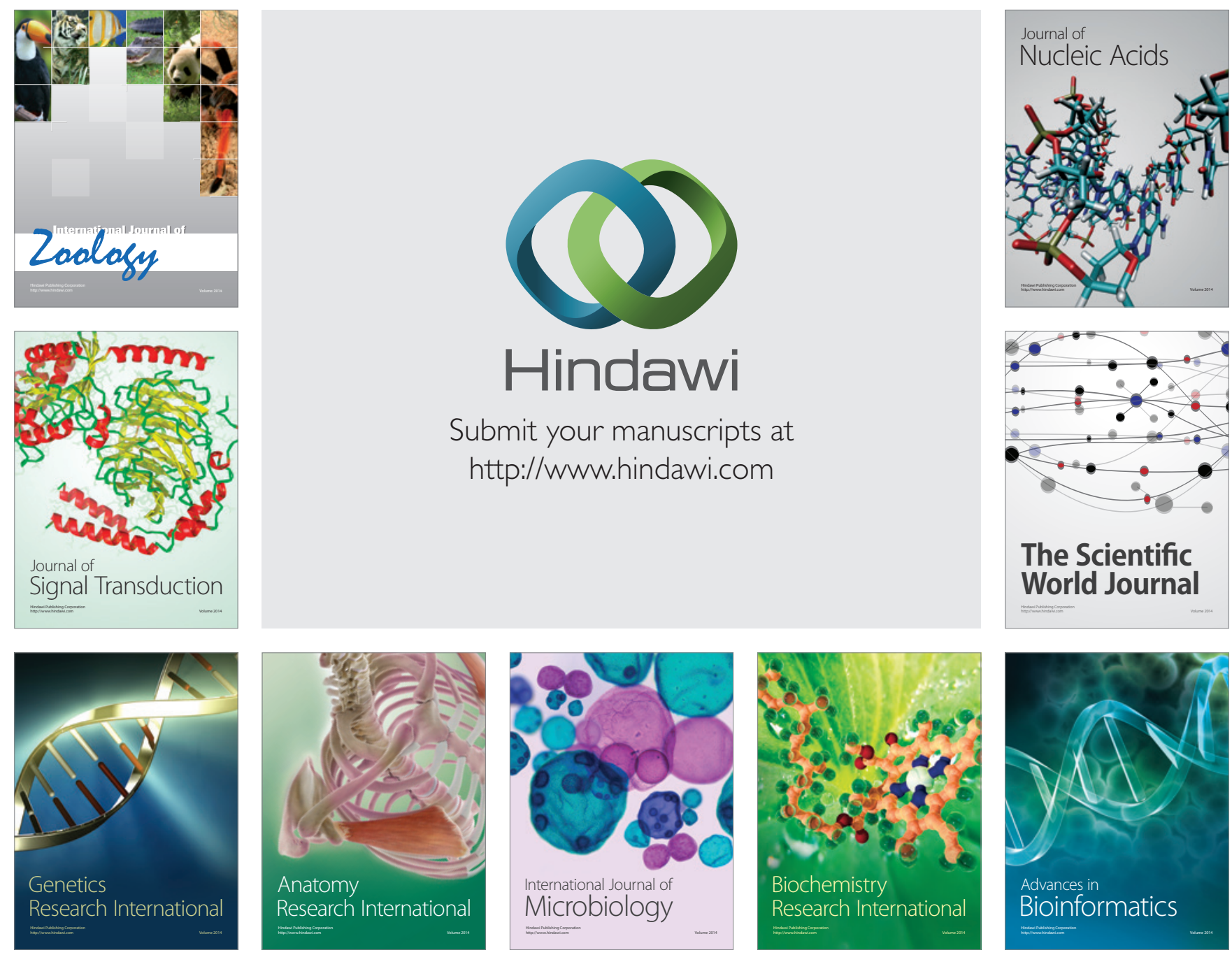

The Scientific World Journal
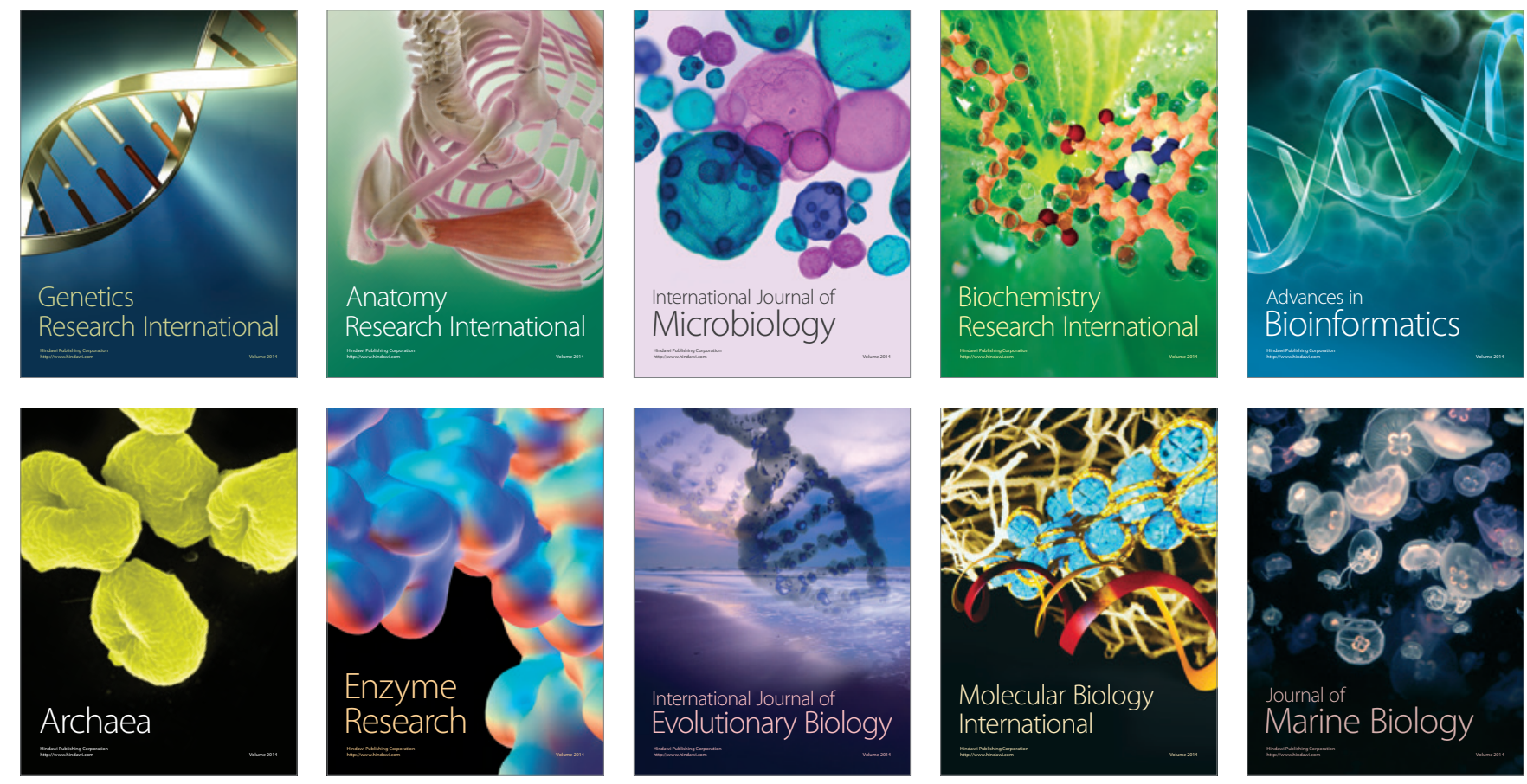